\title{
Anxiety and excitement in the fourth industrial revolution: A systems- psychodynamic perspective
}

\begin{tabular}{|c|c|}
\hline \multicolumn{2}{|c|}{$\begin{array}{l}\text { Authors: } \\
\text { Claude-Hélène Mayer }{ }^{1,2} \text { (1) } \\
\text { Rudolf M. Oosthuizen }{ }^{3} \text { (1) }\end{array}$} \\
\hline \multicolumn{2}{|c|}{$\begin{array}{l}\text { Affiliations: } \\
{ }^{1} \text { Department of Industrial } \\
\text { Psychology and People } \\
\text { Management, College of } \\
\text { Business and Economics, } \\
\text { University of Johannesburg, } \\
\text { Johannesburg, South Africa }\end{array}$} \\
\hline \multicolumn{2}{|c|}{$\begin{array}{l}{ }^{2} \text { Institut für Therapeutische } \\
\text { Kommunikation und } \\
\text { Sprachgebrauch, Europa } \\
\text { Universität Viadrina, } \\
\text { Frankfurt, Germany }\end{array}$} \\
\hline \multicolumn{2}{|c|}{$\begin{array}{l}{ }^{3} \text { Department of Industrial } \\
\text { and Organisational } \\
\text { Psychology, School of } \\
\text { Management Sciences, } \\
\text { College of Economic and } \\
\text { Management Sciences, } \\
\text { University of South Africa, } \\
\text { Pretoria, South Africa }\end{array}$} \\
\hline \multicolumn{2}{|c|}{$\begin{array}{l}\text { Corresponding author: } \\
\text { Claude-Hélène Mayer, } \\
\text { claudemayer@gmx.net }\end{array}$} \\
\hline \multicolumn{2}{|c|}{$\begin{array}{l}\text { Dates: } \\
\text { Received: } 08 \text { June } 2020 \\
\text { Accepted: } 21 \text { Oct. } 2020 \\
\text { Published: } 25 \text { Jan. } 2021\end{array}$} \\
\hline \multicolumn{2}{|c|}{$\begin{array}{l}\text { How to cite this article: } \\
\text { Mayer, C.-H., \& Oosthuizen, } \\
\text { R.M. (2021). Anxiety and } \\
\text { excitement in the fourth } \\
\text { industrial revolution: A } \\
\text { systems- psychodynamic } \\
\text { perspective. SA Journal of } \\
\text { Industrial Psychology/SA } \\
\text { Tydskrif vir Bedryfsielkunde } \\
\text { 47(0), a1813. https://doi. } \\
\text { org/10.4102/sajip.v47i0.1813 }\end{array}$} \\
\hline \multicolumn{2}{|c|}{$\begin{array}{l}\text { Copyright: } \\
\text { (c) 2021. The Authors. } \\
\text { Licensee: AOSIS. This work } \\
\text { is licensed under the } \\
\text { Creative Commons } \\
\text { Attribution License. }\end{array}$} \\
\hline \multirow{2}{*}{ 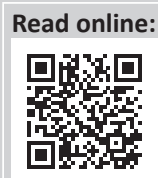 } & \\
\hline & $\begin{array}{l}\text { Scan this QR } \\
\text { code with your } \\
\text { smart phone or } \\
\text { mobile device } \\
\text { to read online. }\end{array}$ \\
\hline
\end{tabular}

Orientation: The fourth industrial revolution (4IR) creates numerous organisational changes. New technologies and their influences are studied; however, hardly any research focuses on studying the unconscious systems psychodynamics (SPs).

Research purpose: The purpose of the study was to explore and understand feelings in an organisational 4IR context from a SP perspective.

Motivation for the study: Scholars have recently issued calls to shift attention from describing the 4IR processes in terms of rapid structural, technological and disruptive changes towards the understanding of subjective 'lived-through' feelings and experiences and in situ responses to 4 IR events. Based on this shift, the authors aim at exploring the 'lived-through' experiences in this study from a SP viewpoint.

Research approach/design and method: This article presents findings from a qualitative study conducted in a technology organisation, analysing 16 interviews with managers in middle and top management positions.

Main findings: The findings show SP playing out in terms of splitting, projection, projective identification and idealisation. Findings with regard to the five fundamental systemic behavioural conventions (dependency, flight/ fight, pairing, me-ness, one-ness or we-ness) are also presented.

Practical/managerial implications: Managers experience anxiety and excitement as strongly influential in the 4IR transformational processes and as playing an important role in SP processes.

Contributions/value-add: Organisations and employees need to be made aware of the new trends in the 4IR and the underlying unconscious processes within the organisation. Employees could undergo training to improve their understanding of intra- and inter-psychological and organisational processes and the impact on organisational change and transformation within the 4 IR contexts.

Keywords: systems psychodynamics; feeling; splitting; projection; projective identification; idealisation; 4IR; anxiety; excitement; organisational change.

\section{Introduction}

The introduction of new digital technologies in industrial companies is creating new sociotechnical interactions between physical and virtual elements, leading to human-related, technical and organisational changes (Becker \& Stern, 2016). Scholars have recently issued numerous calls to shift attention from describing the fourth industrial revolution (4IR) processes in terms of rapid structural, technological and disruptive changes towards the understanding of subjective 'lived-through' feelings and experiences and in situ responses to 4IR events. Using appraisal theories, Barclay and Kiefer (2019) argued that focusing on the employee's perspective highlights the importance of feelings in 4IR experiences. Furthermore, this emphasis creates opportunities for novel insights regarding feelings that are likely to be relevant, the constructive responses that can emerge from anxiety and excitement, and the interplay between these feelings and the 4IR. In order to deal with these changes and the related emerging challenge in the $4 \mathrm{IR}$, there is a need for qualitative research that can serve as the foundation for theories, models and frameworks to guide future research and practitioners in their journey towards the 4IR. By using a psychodynamic lens, this qualitative study attempts to offer novel insights into this phenomenon. The role of negative feelings in the change process has long been discussed in the literature (Mayer, 2020). 
Kiefer (2005) postulated that three main antecedents to anxiety in ongoing change are as follows: perceptions of an insecure future, inadequate working conditions and inadequate treatment by the organisation. Two outcome variables were identified: trust in and withdrawal from the organisation. Regression and path analysis revealed that (1) ongoing changes are associated with anxiety, (2) this relationship between ongoing changes and feelings is mediated by the three proposed antecedents and (3) anxiety predicts employee's lack of trust and employee's withdrawal. The following questions can be asked: How does the 4IR differ from disruptive changes that have been studied before? How do feelings, such as anxiety or excitement, play out differently in the 4IR? However, such qualitative data are minimal (Hoffmann et al., 2019; Schneider, 2018). In this article, we address this gap and present qualitative evidence that illustrates how the 4IR transformations affect feelings in terms of anxiety and excitement in the 4IR context (Kadir \& Broberg, 2020). As a frame of interpretative reference, we use the systems- psychodynamic (SP) theory.

\section{Research purpose and objectives}

The purpose of the study was to explore and understand feelings in an organisational 4IR context from a SP perspective.

\section{Literature review}

Systems psychodynamics are founded in social psychoanalytic, group relations, object relations and open systems theory (Colman \& Bexton, 1975; Colman \& Geller, 1985; Cytrynbaum \& Noumair, 2004; Greyvenstein \& Cilliers, 2012). In theory, it encompasses Freudian systemic psychoanalysis (Freud, 1921), the research of Klein (1988) on family psychology, Ferenczi on object relations and Bertalanffy on systems philosophy (Colman \& Bexton, 1975; Colman \& Geller, 1985; Cytrynbaum \& Noumair, 2004). From a research viewpoint, SP propose a profundity-psychological organisational theory - a developmentally converged, psycho-educational practice aimed at the interpretation of the conscious and unconscious conduct in the organisation (Armstrong, 2005; Campbell, 2007; Campbell \& Huffington, 2008; Huffington, Armstrong, Halton, Hoyle, \& Pooley, 2004; Klein, 2005). The primary task of SP is to provide developmentally and psychoeducationally focused reflection and learning opportunities to the individual manager to study, become aware of and gain insight into how anxiety and excitement are influenced by both conscious and unconscious behaviour (Brunning, 2006; Huffington et al., 2004; Kets de Vries, 2007; Newton, Long, \& Sievers 2006). Consciousness refers to objectivity and rational behaviour and unconsciousness to 'the organisation in the mind', which contains the system's unconscious defences and irrational behaviours (Armstrong, 2005). All of these behavioural assumptions are unconscious experiences (Cilliers \& Terblanche, 2010). The philosophy is centred on five fundamental systemic behavioural assumptions, specifically, dependency, fight/flight, pairing (Bion, 1961, 2003), me-ness
(Turquet, 1974) and one-ness or we-ness (Cilliers \& May, 2010). Fraher (2004) provided an overview regarding the five fundamental systemic behavioural assumptions.

\section{Dependency}

The system needs to be rescued by an omnipotent leader. Dependence shows in employees' relatedness to an inventive, 'fantasised' and caring parental figure (Campbell, 2007). When these needs are not met, employees encounter uncertainty, uneasiness and de-authorisation (Czander, 1993). In such a dependent framework, employees end up being excessively dependent upon each other and the organisation as representatives of authority figures within the organisation (Van der Toorn, Tyler, \& Jost, 2011). When authority figures fail to meet employees' needs, fizzled reliance is predominant (Huffington et al., 2004).

\section{Flight or fight}

The system is under threat and needs to fight an aggressor or needs to get away from danger. These experiences are happening in the (collective) unconscious mind of the system. Fight or flight shows the fighting against or flight away from an imagined enemy (the foe within the intellect) (Bion, 1961; Cytrynbaum \& Noumair, 2004).

\section{Pairing}

The system's survival depends on the connection between two powerful objects to create a father or mother (authority figures/'objects representing authority in the mind') and figure and saviour. Pairing alludes to employees' collective oblivious uneasiness related to inventiveness and progression. It shows the pairing up of seen capable objects based on the confident wish for the birth of a saviour to take the psychic torment away (Colman \& Bexton, 1975).

\section{One-ness or we-ness}

The system's wish to become part of an undifferentiated, homogenous, omnipotent and powerful yet passive union without individuality, differentiation or diversity. One-ness or we-ness shows when employees yield their distinction and mentally connect in a non-existent effective union with a supreme drive in order to encounter well-being and wholeness (Turquet, 1974). We-ness refers to the opposite of me-ness, the unconscious need to join a powerful union with and absorption into an omnipotent force, surrendering the self in passive participation (Lawrence, 1999).

\section{Me-ness}

The system's fear of destructive group processes leads to individual disconnectedness. Me-ness is seen as a versatile resistance showing when individual employees perceive their group's conduct or impact as undermining and scaring. People at that point detach themselves from their group association and depend on their independence and self- 
reliance to manage the demands of their feelings (Bion, 1961; Steyn \& Cilliers, 2016).

Systems psychodynamics postulate an organisational theory concerning the perception and elucidation of systemic configurations and its connection to deep contained, unconscious and tacit individual, social and organisational anxiety (Armstrong, 2005; Gould, Stapley, \& Stein, 2006). Bion (1961) conferred that exposed organisations operate in two kinds of procedures: the working group refers to the conscious attention on the complex organisational task, whilst the central group performs unconsciously in congruence or incongruence with the working group with the task to decrease anxiety in order to continue to exist (Steyn \& Cilliers, 2016). Systems psychodynamics foster knowledge concerning the conscious and unconscious psychodynamics working in an organisation (Amado, 1995; May, 2019; Mayer, Oosthuizen, Tonelli, \& Surtee, 2018). Applying the SP perspective empowers consultants, researchers and others to work with 4IR conscious and unconscious crescendos, organisational composition and strategy and the collaboration between the two (Mayer, 2020).

\section{Anxiety}

In this research, anxiety is demarcated as the organisation's unconscious propelling energy (Huffington et al., 2004) to control the trepidation of the 4IR. Anxiety acts as the thrusting power in the organisation's unconscious and could manifest as free-floating (a persistent improbable prospect separated from a distinctly framed object of fear), endurance (the supposition that life is endangered), performance (the supposition that an individual's value is lower than what is deemed at the time) and paranoid anxiety (constructed on the conviction in a possibly impairing adversary) (Farlex Medical Dictionary, 2015; Menzies, 1993; Schein, 2009). Subsequently, the system protects itself against the anxiety (Sievers, 2009). This is portrayed as the paranoid-schizoid stance (Klein, 1975) where the organisation experiences anxiety enthused by inflexibility in thoughts, fear of the 4IR and of torment, and imaginations of magnificence (Krantz, 2001), which are fortified against through splitting, projection, projective identification and idealisation (Blackman, 2004). From a theoretical research perspective, anxiety as an SP construct is applied in this research as a depth psychology experience driving unconscious behaviour towards survival of the group.

\section{Splitting}

According to Klein (1946), splitting of the object into good and bad is closely associated with extremely violent, sadistic impulses, which the child makes in desperate attempts to deal with a situation. The ego is not subjected to a passive split but actively employs splitting to defend against anxieties threatening its cohesion. In early life, splitting is a normal defensive mechanism, protecting the ego and the object from the death instinct. Splitting is an attempt of the early ego to achieve order and organisation (Klein, 1946, 1952). It seems that at this stage of development, the unification of external and internal, loved and hated, real and imaginary objects is carried out in such a way that each step towards unification leads to a renewed splitting in the images (Savvopoulos, Manolopoulos, \& Beratis, 2011; Tenconi, 2020).

\section{Projection}

Splitting of the ego is followed by the projection of the sadistic part of the ego onto external reality so that it is perceived as part of someone else's identity (Diamond, 2020). Projection, a more mature form of defence, consists of first repressing the intolerable experience, then projecting the experience onto the object and finally separating or distancing oneself from the object to fortify the defensive effort (Klein, 1946, 1952). This process is called projective identification (Savvopoulos et al., 2011).

\section{Projective identification}

Projective identification is essentially a primitive defence mechanism. The subject projects intolerable intrapsychic experiences onto an object, maintains empathy with what he projects, tries to control the object in a continuing effort to defend against the intolerable experience, and, unconsciously, in actual interaction with the object, leads the object to experience what has been projected onto him (Kernberg, 1987). It predominates in psychosis where it is accompanied by loss of reality testing, and, from a structural viewpoint, by the loss of boundaries between self and object representations (Diamond, 2020).

\section{Idealisation}

Melanie Klein (1946) described idealisation as part of an early defensive splitting and idealisation in which, in an effort to deal with overwhelming instinctual forces of life and death, good and bad aspects and experiences of the object are in phantasy kept apart (Mollon, 1986). An idealised object is sought to protect against a persecutory one. Thus, the idealisation may focus on the functional capacities of the object rather than the person per se. In idealising transference, it may be the process or technique of analysis that is idealised (Ployé, 1984; Tenconi, 2020).

If the organisation can manage the anxiety of the 4IR successfully towards the incorporation of its effective and ineffective elements into a resilient entity and reject the idea of the perfect entity, the organisation can retain its real behaviour and repair its entity and employee relationships (Cytrynbaum \& Noumair, 2004; Steyn \& Cilliers, 2016).

\section{Excitement}

Excitement is originally not a common feeling that is described in SP; however, it is a feeling that occurs under the surface in this research and is part of the dynamics that play 
a role in the 4IR transitions because it is mentioned as a driving force in the 4IR and becomes part of the SP in the way that participants refer to it in strong connection with the anxieties they experience personally and within the group dynamics. Therefore, excitement is an important part of the group dynamics that impact the processes within the organisation.

Excitement includes cognitive, emotional, behavioural and physiological components, including stimulation. These components incorporate: (1) centring attention on the source of the excitement, for example, an energising movement, (2) feeling energised and lively, (3) acting with vigour, (4) having raised excitement, including increased heart rate and blood sugar and (5) having a by and large positive subjective involvement (Cannon, 1952). People shift in how much energy they need, how much excitement they experience in life and what they discover as energising (Apter, 1992). Excitement might be characterised as sensation seeking or as an identity characteristic that includes looking for sensations, even at considerable risk (Poole \& Malouff, 2019; Zuckerman, 1979).

Excitement is a conceivable way to high positive influence, which in turn is related to numerous positive characteristics and results (Watson, Clark, \& Tellegen, 1988). Positive affect leads to more prominent adaptability in considering and in openness to modern thoughts and encounters (Fitzpatrick \& Stalikas, 2008b). People who experience more positive feelings appreciate more diverse and fulfilling social lives and stronger immune systems and they live longer (Kok et al., 2013; Lyubomirsky, King, \& Diener, 2005). Positive feelings can encourage versatile changes and adapting capacities (Fitzpatrick \& Stalikas, 2008a; Folkman \& Moskowitz, 2000) that encourage mental well-being. Positive feelings tend to broaden mindfulness and to extend investigation in thinking and activity (Poole \& Malouff, 2019).

Studies have indicated that it is conceivable to extend the level of positive affect. Meta-analyses of the impacts of mediations found that such interventions have noteworthy impacts on positive influence or the related development of happiness (Bolier et al., 2013; Sin \& Lyubomirsky, 2009). There is also reason to accept that positive influence can be expanded by maximising life excitement. Fourth industrial revolution's disruptive change can take many forms. It may be equivalent to or an extension of something familiar, it may restore expertise in an aspect of practice long forgotten and it may add skills and experience without a sense of loss. Although the change towards the 4IR may break important attachments to ways of working and expose relatively trivial habits and expectations, it may, at the same time, launch a new and exciting enterprise or endeavour (James, 2010). Moreover, whilst the change may generate great anxiety and apprehension, there is no powerful sense of loss; the change may even be experienced as exciting and energising. However, the change can bring a loss of purpose, which will relate to considerable mental disturbance resulting from internal conflicts and the loss of meaning (Marris, 1974). It is assumed here that in the organisation, not only anxiety plays a major role in the group dynamics of transitioning into the $4 \mathrm{IR}$, but that excitement, as an important feeling and counteractor of anxiety, also plays a major role in ensuring the survival of the group and keeping the drivers in the organisation together to cope with the 4IR changes.

\section{Research design}

\section{Research approach}

The study used a post-modernist, qualitative research approach (Creswell, 2013) inside the hermeneuticalphenomenological research worldview to investigate and understand the subjective encounters and socio-cultural settings of the managers and the elucidation of encounters through the researchers (Clarke \& Hogget, 2009; Creswell, 2013; Hassan \& Ghauri, 2014).

\section{Research strategy}

Systems psychodynamics are a systemic paradigm - it interprets collective behaviour - the individual represents the team. The interpretations given here are about managers and not the system.

\section{Research method}

A qualitative study reflects that the diversity of individual viewpoints on the specified topic of anxiety and excitement in the 4IR will potentially reveal new or dissimilar themes (Yin, 2009; Zach, 2006).

\section{Research setting}

The study was conducted in a German world-leading, innovation organisation, working particularly with fabricating. The organisation creates specific pumps and mechanical valves and centres on the zone of water and water waste administration, gives state-of-the-art mechanical applications, with respect to process designing, extraordinary processes, chemical businesses and marine applications, as well as warming and cooling frameworks. The yearly benefit income of the organisation is within the extent of $€ 2200$ million euros. The organisation alludes to the German Corporate Administration code and values a corporate culture, which incorporates professionalism and commitment, proactive planning, trust, genuineness and responsibility, as well as appreciation. The organisation's central values incorporate excellence, unwavering quality and innovation-driven victory and it is working in over 100 nations around the world.

\section{Entrée and establishing researcher roles}

One of the researchers was working as a leadership specialist for the German head office. During the counselling sessions, the thought was born to conduct qualitative interviews with managers within the organisation to 
advance the understanding of the managers and their views with respect to the change towards the 4IR. The research group comprises two researchers, one German female and one South African male researcher.

\section{Research participants and sampling methods}

Only one organisation participated in this study, to be specific, the South African appropriation of the German designing organisation. The managers working in the organisation were included in the study (Shaheen \& Pradhan, 2019) based on criteria of consideration, such as managerial leadership role, position within the association and tenure inside the organisation. As a result of privacy reasons, biographical information will not be disclosed. However, as indicated in Table 1, it can be specified that nine managers are English speaking, four are Afrikaans speaking, two are bilingual (Afrikaans and English speaking) and one is German speaking. The age range of members is from 32 to 60 years. Managers worked for the organisation for between 2 and 25 years. They work in top and middle management positions in the areas of production and planning, building, finance, technical, projects, human resources, sales, distribution centre, service and operations. Out of the 16 managers, 15 are men and one is woman.

\section{Data collection methods}

The researchers conducted 60-75 min interviews, which were semi-structured in nature and contained 20 interview questions. The rationale of the interviews included the exploration of the underlying group dynamics within the organisation and the feelings that play a role in these dynamics based on SP theory. One of the main questions investigated in this article was, for example What feelings do employees experience with regard to the 4IR as underlying group dynamics?

\section{Data recording}

Data were recorded through field notes and audio recordings as indicated by participants' inclinations. Audio recordings were transcribed verbatim, and data are stored electronically for a period of 5 years in password-encrypted data files. Printed copies were stored safely by the university under the examination arrangements and methodology of the university with no entrance to the research by the general population.

\section{Data quality and integrity}

Managers shared rich and detailed information, through subjective encounters that lead to meticulousness in the quality of the information, its investigation and translation (Johnson, Adkins, \& Chauvin, 2019). The analysts utilised diverse sources, strategies and hypothetical approaches to guarantee validity through triangulation (Creswell \& Plano Clark, 2011). Confirmability and transferability of information (Creswell, 2013) were advanced through intersubjective approval forms and the use of set up hypotheses and strategies, which were built up amongst the researchers (Yin, 2014), whereas thoroughness was advanced through abundant depictions and direct forms. The study further gives an in-depth understanding of the discoveries and themes but does not give generalisability (Creswell, 2013; Lincoln, \& Guba, 1985).

\section{Data analysis}

The analysis of information was conducted through five steps as depicted by Clarke and Hoggett (2009): (1) the information was subjected to an introductory, preparatory and all-encompassing evaluation, (2) topics were produced, (3) information was coded, (4) the body of the content was broken down into important sections that were named and (5) close consideration was given to the nuances and subtleties of the meaning inalienable within the information by the researchers (Clarke \& Hoggett, 2009). Information was recorded as audio-recordings and translated verbatim. Field notes were taken amid interviews. Information will be saved electronically for a period of 5 years. The information records are password encrypted.

\section{Reporting style}

The findings are reported in a qualitative reporting style, which supports the insight into the research into SP.

TABLE 1: Demographical data.

\begin{tabular}{|c|c|c|c|c|c|}
\hline Interviewee number & Duration in organisation & Age (years) & First language & Sex & Ethnicity \\
\hline P1 & 10 years & 35 & English & Male & White person \\
\hline P2 & 12 years & 37 & English & Male & Indian person \\
\hline P3 & 13 years & 47 & English & Male & White person \\
\hline P4 & 25 years & 47 & English & Male & White person \\
\hline P5 & 11 years & 34 & Afrikaans & Male & White person \\
\hline P6 & 7 years & 58 & English & Male & Indian person \\
\hline P7 & 6 years & 33 & Afrikaans and English & Male & White person \\
\hline P8 & 5 years & 35 & Afrikaans & Female & Mixed person \\
\hline P9 & 4 months & 56 & German & Male & White person \\
\hline P10 & 13 years & 43 & Afrikaans & Male & White person \\
\hline P11 & 2 years & 32 & English & Male & White person \\
\hline P12 & 20 years & 47 & English & Male & White person \\
\hline P13 & 13 years & 43 & Afrikaans & Male & White person \\
\hline P14 & 14 years & 57 & English & Male & White person \\
\hline P15 & 18 years & 55 & English and Afrikaans & Male & White person \\
\hline P16 & 14 years & 60 & English & Male & White person \\
\hline
\end{tabular}




\section{Ethical consideration}

Ethical approval to conduct the study was obtained from the ethics committee at the Division of Industrial Psychology and People Management of the University of Johannesburg. The organisation gave permission to conduct the investigation and members gave written consent. All members were educated regarding privacy and their rights as members.

\section{Results}

The findings indicated that managers in the organisation refer to positive and negative feelings during their interviews on transformational processes with regard to the 4IR. Negative feelings are more frequently mentioned in the data set than positive feelings. In the 'Negative emotional experiences' and 'Positive emotional experiences' sections, the findings with regard to positive and negative feelings towards the 4IR are presented and the findings are interpreted in the 'Discussion' section. Overviews of the feelings mentioned by the managers are presented in Tables 2 and 3. In the 'Discussion' section, the SP interpretations of the findings are provided.

\section{Negative emotional experiences}

Altogether, managers gave 32 statements with regard to negative emotional experiences within the 4IR changes of the organisation. Eight out of 16 managers pointed out that they are very excited about the times they live in and the changes the 4 IR brings.

Table 2 indicates that most of the negative emotions and feelings experienced are not only connected to expressions of fear, anxiety and trepidation but also to worry and concern. Several managers also feel challenged, stressed or frustrated and some described their mindset just as 'negative'. Furthermore, statements of single individuals

TABLE 2: Negative feelings towards the fourth industrial revolution.

\begin{tabular}{ll}
\hline Negative feelings & Participants \\
\hline Fearful, anxious, scared and trepidation & P1, P2, P6, P7, P8, P10, P11, P13 \\
Concerned and worried & P4, P9, P10, P11, P13 \\
Stressed and threatened & P7, P10, P11, P13, P15 \\
Challenged & P2, P9, P13, P15 \\
Frustrated & P6, P13, P15 \\
Negative mindset & P12, P13, P15 \\
Panicked & P11 \\
Shocked & P7 \\
Uprooted & P14 \\
Loss of faith & P13 \\
\hline
\end{tabular}

TABLE 3: Positive feelings towards the fourth industrial revolution.

\begin{tabular}{ll}
\hline Positive feelings & Participants \\
\hline Excitement & P1, P3, P5, P7, P8, P9, P12, P15 \\
Positive in general because of new advantages & P1, P7, P8, P9 \\
Happy and positive about new learnings & P1, P8, P9 \\
Not scared at all & P5, P9 \\
Motivation to overcome negativity & P13, P16 \\
Love for new era & P12 \\
Empowerment & P12 \\
\hline
\end{tabular}

referred to panic, shock, up-rootedness or loss of faith. The descriptions showed that the feelings are experienced as painful and upsetting, uncomfortable and unpleasant. Often, there are no particular described incidents related to the feelings. Rather, they are experienced as diffuse feelings that are connected to an overall, holistically experienced situation of change, insecurities and unexplored territory but are hardly connected to specific situations, events or experiences.

\section{Positive emotional experiences}

Managers also provided 21 statements on the 4IR changes and their emotions that are defined as positive.

Exploring the feelings that are experienced as positive, it can be stated that half of the managers interviewed expressed excitement when talking about and experiencing the 4IR changes. Usually, they are excited, because they experience new and unknown territory, being part of the process of something new, of a new era and intriguing organisational developments. Several managers did not describe feeling as such but they are 'positive' about the 4IR advantages, and some highlighted happiness and positivity about new learnings. Two individuals expressed their positive attitude by not feeling anxious or scared. Two other managers felt motivated by the changes and one manager felt love for the era and empowerment. It is important to notice that several of the managers indicated that they experience both positive and negative feelings and emotions with regard to the developments of the 4IR.

\section{Fourth industrial revolution-evoked feelings}

P1 pointed out that the employees are very scared about the changes happening within the organisation:

'I think, originally, they were a bit scared because they think the system is automated; you don't need them anymore. You know, because the system is doing the work for the air. But you need the person behind the system to ensure that it's running effectively, otherwise you could end up buying components that are no longer needed, the customer cancels the order, some customers they, during production, they decide, no, I need two more pumps or something.' (P1)

At the same time, P1 pointed out that, for himself, personally, the changes of the 4IR are positive and exciting:

'For me? It's positive personally; because, maybe because, more
so because of the type of work I do. I like seeing new technologies,
I like doing research. So, I think for me, it's all positive. Because
it's something new that anything new is always exciting. And it's
a bit fearful on the one side. Ja, but it's more excitement because
I get to see things that you probably would never ever have
thought about before.' (P1)

P1 explained that employees feel scared by the changes. By highlighting this, he emphasised that employees should not feel scared but rather assured that they are still needed to make sure the system runs effectively and to do the controlling 
of the machine processes. At the same time, he said that he is positive about the $4 \mathrm{IR}$ processes based on the work he does and because of his passion to work with new technologies and to do research. Therefore, his positive feelings are connected to excitement about novel processes and he admitted that he is only a bit fearful. He thereby splits himself from the common employee's feelings and experiences by differentiating between their jobs and his job.

A similar statement was given by P7 who highlighted that he experiences trepidation with regard to the 4IR changes, but also that his own excitement is bigger than his fear:

'If I think about the fourth industrial revolution, I do actually have a sense of trepidation. But, a big but, I'm actually quite excited. I mean, if you go and think about the amount of technologies that are coming forward, the amount of opportunities coming forward.' (P7)

Similar to P1, P7 admitted that he has a sense of trepidation about the future, but also his primary feelings are positive and excited with regard to the advances and opportunities ahead. Even the following participant pointed out that the future is insecure, challenging, interesting and exciting at the same time. P9 also indicated what both sides of the coin of the 4IR were for him:

'As a person, I do not know what will come in the future, but I think it is challenging and it's interesting for me, I'm really very positive about that I like changes, whenever they occur and... it's there. We should grab it. We should look for it. I'm very positive about it. Ja.' (P9)

P9 was generally positive about the changes and highlighted that when changes occur, people should look at them carefully and grab their opportunities. It means that people should behave proactively towards the changes and use them for their own betterment. P7 emphasised that he is actually very positive about the 4IR as well, but he can also empathise with individuals who lose their jobs and feel shocked and stressed about the 4IR processes:

'I would actually say positive for the most part. As we say, if we run with our hypothesis that it will allow more freedom, more efficient working gives more freedom, more freedom gives more personal time and that takes away a lot of stress. So that in and of itself is an inherently positive thing to have. The health of people that might be replaced by it, that can be a different story. Let's face it if you're replaced by a robot, and told that you're redundant now, it's gonna be quite shockingly stressful.' (P7)

P7 connected the experienced positivity to values that are important to him and that are supposed to come with regard to 4IR, namely freedom, efficient working and more personal time. In this sense, $4 \mathrm{IR}$ processes may decrease stress for the participant himself, but it might be very stressful for employees who are replaced by robots. P16 referred to stress - not caused by the fear of being replaced, but rather by his idea of having to move with the pace of the 4IR himself:

'It makes you more stressed. Because it's just too quick; they can find you anywhere, you've got to - expect you to answer emails.
If I go outside the country, now I can bring my computer with me whereas before it was impossible. So, provided I can access emails, I've got to return to where I'm staying and then download emails and answer them.' (P16)

This manager is worried and stressed by always being accessible and available all over the world. He is stressed that there is no external boundary, but that he has to set the boundaries himself in demarcating the influences coming to him through digitalisation and, in future, probably even more through 4IR technology.

P14, being asked about his feelings with regard to the 4IR, said:

'It's definitely resistance to change. I do pick that up a lot, but it's a case of, you know, winning them over. You've got to explain, explain it in depth. Explain the advantages. And in the long run, what are the benefits to the company to get them to buy into it. But it's a lengthy process. And I don't think it will happen overnight. But I think the main thing for digitisation, lean manufacturing, is to communicate and to get their cooperation.... You know a lot of the people will be uprooted. It'll maybe take a few of their jobs away.' (P14)

This manager picks up feelings of resistance to change in the employees and he provides ideas for how to motivate employees to overcome their resistance (personal motivation, advantages and organisational benefits). He emphasised that many employees will be 'uprooted' and many will lose their jobs. By presenting his opinion, it is obvious that he sees himself as a positive force of the 4IR and the employees carrying a negative mindset, who need to be convinced to adopt a positive mindset.

This is in contrast to P13's comment when he highlighted that $70 \%$ of the employees, including himself, have lost faith in the new technology because of failures in the broader systems of society (Internet systems, etc.). P13 is very critical about the 4IR process and comments:

'I would say $70 \%$ of us have lost faith in technology in the company - because we've always had this internet problems and problems. So, nobody believes that the next step up is going to be any better. So, I think, that is going to be a big challenge ... I think that's part of the reason why people are scared about it, because I think they don't realise what the potential is. And when you start talking about the potential, they feel threatened as, as, as maybe a race or a species or - no, we don't want to make that happen.' (P13)

P13 feels that the move into 4IR is a huge challenge and because people are aware of the failure and problems in the wider societal systems, people are scared of the changes to come. He also then separated himself from the normal employee by highlighting that he can point out the advantages and potentials of the 4IR technology, but he said that employees are, on the one hand, scared to hear about the potential changes and, on the other hand, scared about the consequences of the changes in and the influences on their own life. 
Finally, P15 repeated the stress of previous speakers and pointed out that he is stressed because of the situation with his staff, not because of the 4IR itself:

'I say this to you: I'm a stress ball in the moment. And why am I? It's my staff. They been with me for 18 years, 16 years, 14 years, 10 years minimum. Okay. And I look at what they went through at the moment - and this is not proper. Ai, this is just moving information to another place for them to do their jobs - and they don't know what's going to happen to them. Now I stand there and I say to them, "Your jobs are secure; you might not be working in this department maybe. But you have got jobs," because .... They have not retrenched once. But, there's always a first time. And that's what I fear.' (P15)

In this comment, it is obvious that this manager is stressed for the long-term employees in the organisation who struggle to adjust to new information systems. The manager realised that these employees still struggle with 3IR digitalisation processes whilst the world has moved on to 4IR. He thereby positions himself as knowledgeable of 4IR processes and as prepared to take the route, but he feels that particularly the older generation of employees is not adjusting to the changes that they should have adjusted to long ago. He personally fears that the day will come when the organisation will start retrenching employees whilst he has promised them for some time that the company will not do this. So, he actually does not fear the 4IR himself, but for the consequences the employees will have to cope with 1 day.

\section{Discussion}

\section{Outline of the results}

\section{Hypothesis}

The study aims to explore the 'lived-through' experiences in this study from a SP viewpoint, because subjective feelings have hardly been explored in empirical studies in 4IR transformations up to now and those, being part of SP perspectives in the 4IR, have also hardly been recognised in the sciences.

It was assumed in this study that in the organisation, it is not only anxiety that plays a major role in the group dynamics of transitioning into the 4IR, but excitement as an important feeling and counter-actor of anxiety also plays a major role in ensuring the survival of the group and keeping the drivers in this organisation together to cope with the 4IR changes.

The findings showed that within the dynamics and changes in the organisation to meet the expectations and challenges of the 4IR processes, the group of managers experience a split in their emotional experiences regarding the 4IR with regard to the rapid and disruptive changes within the organisation. On the one hand, they are excited and view the experiences positively; on the other hand, they are anxious and view the experiences negatively. The feelings all relate to different processes within the organisation, which are rapidly changing because of the $4 \mathrm{IR}$, such as the turn towards automation and digitisation and the development of new products. Anxiety most certainly causes an individual to be anxious (Huffington et al., 2004) about the anticipated changes brought by the 4IR, such as rising unemployment, whilst the excitement contributes to them adapting more easily (Fitzpatrick \& Stalikas, 2008b), increasing mindfulness and being active (Poole \& Malouff, 2019). Focusing on the SP processes highlighted by Fraher (2004), the following can be presented.

\section{Dependency: Rescue by omnipotent leader}

From the findings, it could be seen that managers highlighted that the new and omnipresent leader is not a person anymore, but because of technological change with all the processes and dynamics that evolve because of new technological inventions, technology is the unconscious leader of organisational dynamics. Underneath the surface, the findings further showed that anxiety leads unconscious group dynamics and steers how individuals in the system react to the changes and how they foster or reject the technological processes (refer to Figure 1).

The manager (working group) in the organisation promotes the transformation, whilst the employees (Bion, 1961) perform unconsciously in incongruence with the working group (Steyn \& Cilliers, 2016), thereby manipulating and slowing down the process of transformation. This reduces anxiety within the system - for example, of rapid loss of jobs or the inability to cope with the change. According to previous researches (Armstrong, 2005; Gould et al., 2006), feelings of anxiety concerning the perception and elucidation of systemic configurations and their connection to deep contained, unconscious and tacit individual, social and organisational anxiety are also addressed in this organisation and projected on the 4IR process. New technology, the rapid changes towards the 4IR and the related insecurities regarding the way forward and what the changes evoke, bring out deep anxieties, as indicated in the findings. Hence, anxiety seems to be deeply entrenched in the organisation, propelling energy to control it, as described in Huffington et al. (2004). Anxiety can take various forms within an organisation (Farlex Medical Dictionary, 2015; Menzies, 1993; Schein, 2009), and it seems that in this organisation endurance and the feeling that life and survival are endangered seem to be deeply rooted. Furthermore, it might be assumed that anxiety also relates to the feeling of being diminished and de-authorised and that the individual's value is lower than the importance of the technological change - representing performance anxiety towards overwhelmingly performing technology.

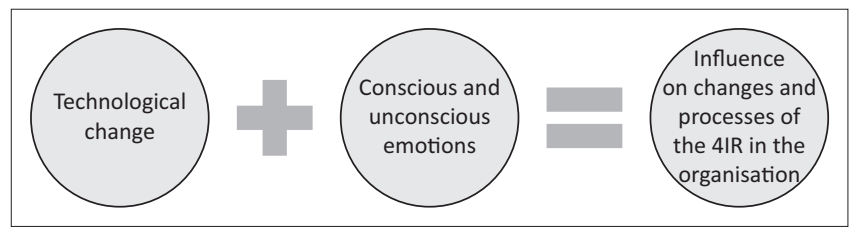

$4 I R$, fourth industrial revolution

FIGURE 1: Technological change and emotions. 
Finally, the findings confirm previous research studies that emphasised that anxiety needs to be contained in an effective way to create resilience (Cytrynbaum \& Noumair, 2004; Steyn \& Cilliers, 2016). It seems that technological advancement - having turned into the overall authority within the organisation - does not meet the employees' needs for inventive care in leadership and rather creates uneasiness and uncertainly within employees (Czander, 1993).

\section{Flight or fight: The system is under threat}

The findings showed that managers described both a flight and a fight reaction, experiencing the rapid change as an aggressor and a danger for their own and the organisation's survival. They highlighted that, on the one hand, they fight for the process of transforming towards 4IR, mentioning feelings of excitement, happiness, empowerment and motivation, whilst on the other hand, describing the fear that leads them to retract (at least intra-psychically) from the change and process. This is shown by splitting the group of managers based on the described feelings towards the 4IR. On the one hand, interviewees described the experiences as exciting and fascinating in terms of advantages, whilst on the other hand, they experienced deep group anxiety. Here the splitting is primarily shown by describing the fear and anxiety of the employees and the excitement of the managers themselves (refer to Figure 2). Several managers presented themselves as carriers of a positive mindset and excited whilst they see the employees are anxious, worried and concerned. This shows not only a strong split in the group of employees but also a split with regard to the managers' reactions: they see themselves as the fighters for the $4 \mathrm{IR}$ changes and for the advancements, whilst they define the employees as being in a state of flight (intra-psychologically), not realising the holistic impact of the 4IR changes, pretending not to know or not to be aware of the changes (internal splitting). At the same time, there occurs an external splitting in the way that managers presented themselves as the 'inner' of the 4IR, being motivated and excited, and in a position where they are not threatened by job losses, whilst they presented their employees as the ones hit negatively by the 4IR and, therefore, fleeing from realising and proactively tackling the changes. Some managers also admitted that they feel anxious, but emphasised strongly that the

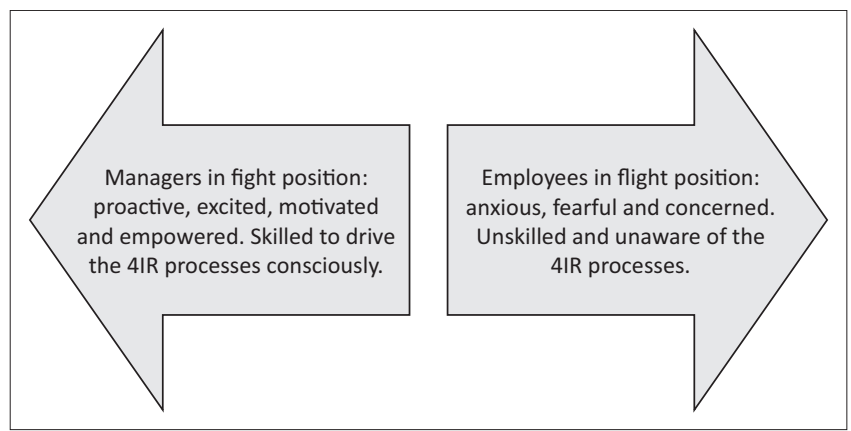

$4 I R$, fourth industrial revolution.

FIGURE 2: Splitting of managers' and employees' mindset and emotions towards the fourth industrial revolution. excitement about the advances and advantages of the 4IR is much greater than the anxiety and fear and the disadvantages.

\section{Pairing: Creating a father figure and saviour}

The findings showed that managers presented the technological change and advancement as the omnipresent leader of the organisation, whereby they experience a split mind about the technological leader's benevolence towards the employees. They are unsure whether the new leader is good or bad for them and they unconsciously search for saviours within the system. These saviours in the process are defined as the proactive, well-skilled managers, as well as the newcomers and the new, technologically affine generation of employees within the organisation. The ones (hopefully) saved are the unskilled, passive employees and the older generation employees who are not knowledgeable of stateof-the-art technology. The technologically knowledgeable, skilled new generation is viewed as the saviour, together with the new technological advantage and the unskilled are those to be saved. The managers unconsciously pair with the 'technologically advanced new generations', or the upskilled (refer to Figure 3).

This pairing process of different ascribed characteristics, feelings and representations is based on projections (Diamond, 2020) as a defence against the own, internal anxieties and fears. Here managers projected several negative aspects (unconsciousness, knowledgeability, fear, worry, concern, being left behind and losing their jobs) on the employees to distance themselves from the dangerous side of the 4IR (see also Klein, 1946, 1952). At the same time, they paired with the technology, the advanced and upskilled new generation to overcome their fears themselves.

\section{One-ness: The system's wish to become part of an undifferentiated, homogenous, omnipotent and powerful yet passive union without individuality, differentiation or diversity}

A few, but not many, of the managers emphasised that the 4IR is a global force and that the entire organisation has to manage the rapid changes and new technologies to be part of the global process. Thereby, managers, as elements of the system, unconsciously aim to present a one-ness of the organisational system, on the one hand, and of the global community, on the other (refer to Figure 4). By describing their own anxiety even when it is overshadowed by the great excitement, as described - the description of the 'small' anxiety of themselves

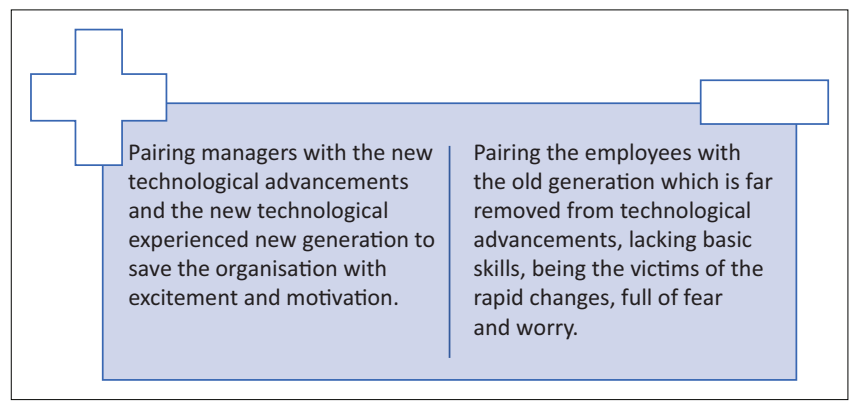

FIGURE 3: Pairing. 


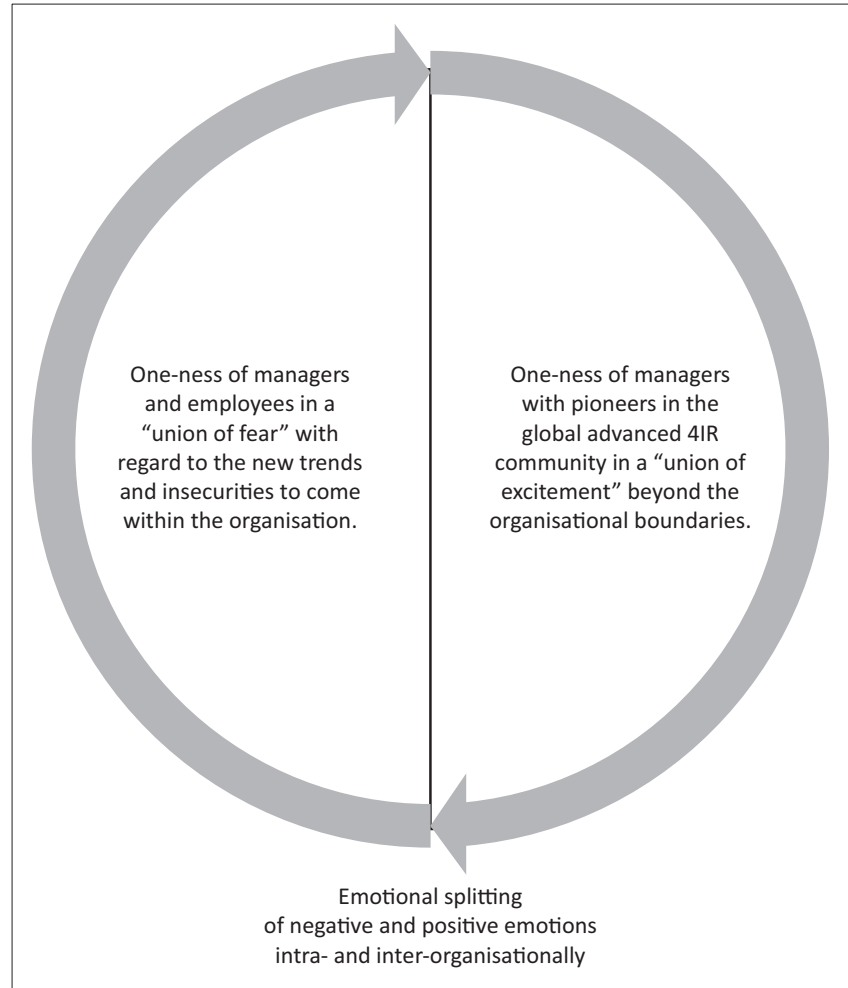

$4 I R$, fourth industrial revolution

FIGURE 4: One-ness.

and the 'big' anxiety of the employees unconsciously aims to create a 'one-ness', a passive 'union in fear' in which the individuality, the differentiation and diversity within the organisation loses weight, whilst the union of all employees, including the managers, gains weight. The fear supports the experience of the one-ness in the system.

Furthermore, managers try to create a union between themselves (as knowledgeable representatives of the organisation) and the advanced global 4IR community. Here, managers become 'one' within the 4IR processes whilst describing their excitement for the new technologies and the new worlds that are open to be explored in a 'union of excitement'. However, this could also be interpreted as part of identification. The negative union through anxiety brings all the employees together, whilst the positive union connects the managers with other managers and pioneers abroad. There is also a split between the negative and positive emotions, keeping the emotionally negative-based one-ness within the organisation, aiming to balance it by connecting globally and creating a positive-based one-ness with potential global players of the 4IR community.

\section{We-ness refers to the opposite of me-ness}

Managers also presented the dynamics of we-ness during the interviews, thereby displaying their need to join with the powerful and omnipresent force (Lawrence, 1999) by describing their excitement, happiness, motivation and feeling of empowerment towards the 4IR. This might be a sign of the unconscious need to join into a powerful union with the $4 \mathrm{IR}$ processes, to ride the wave of the powerful force

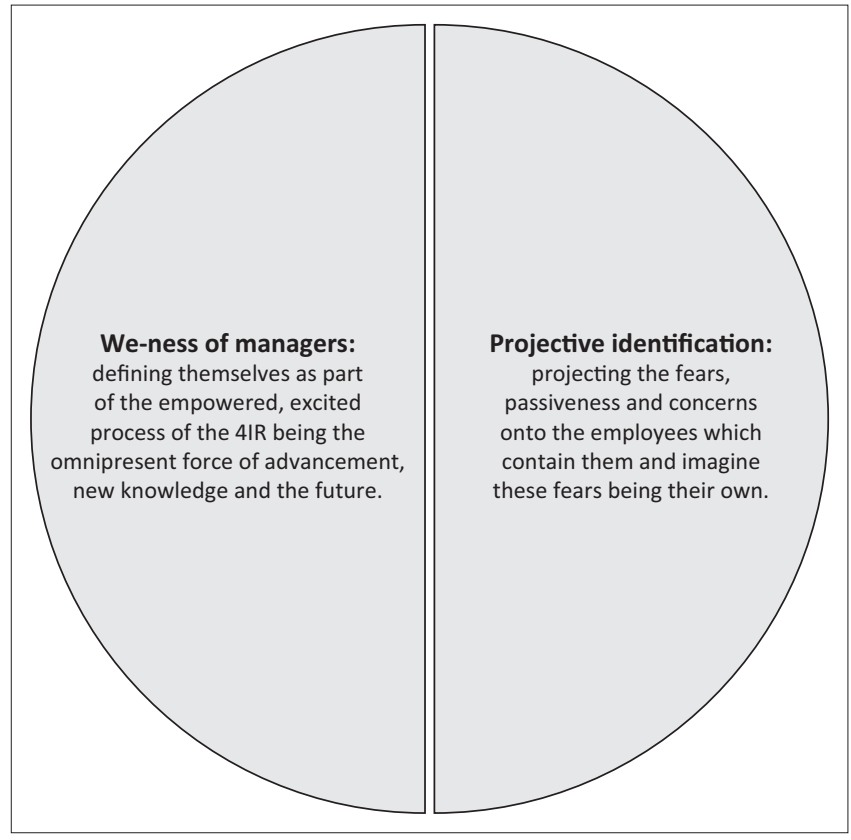

FIGURE 5: We-ness and projective identification.

and becoming a part of it. This idea of being a strong part of the technological changes and advances, and feeling empowered, might also be seen as a projective identification (refer to Figure 5) (Diamond, 2020; Kernberg, 1987).

In this case, managers further projected their intolerable feelings in terms of projective identification (Diamond, 2020; Kernberg, 1987) (described as little trepidations, small concerns) onto the employees, thereby highlighting their empathy for the employees' fear of potential loss of job, being left behind by the rapid processes, being unknowledgeable or even incapable of containing the change and proactively tackling the way in which 4IR should be actively addressed and formed by the individuals. They then described these feelings and processes as being part of the employees' own experiences.

\section{Me-ness: The system's fear of destructive group processes}

Managers described the fear (projected mainly on the employees; however, some managers also describe their own 'little anxiety') to be disconnected; not to be part of the 4IR process; and not to be 'good enough', strong enough, educated and informed enough of technological processes. However, a destructive process is described in several of the statements in which managers emphasised that they hope that the organisation would not retrench employees. At the same time, however, they emphasised that they fear that the organisation might release employees, disconnecting themselves unconsciously from the organisation and from the processes at play by indirectly highlighting that they, as managers, do not have a say in this process (refer to Figure 6). They presented themselves as connected to the employees, but they did not take responsibility for the potential destructive group processes that might play out, for example, through competition, retrenchments, imbalances in skills 


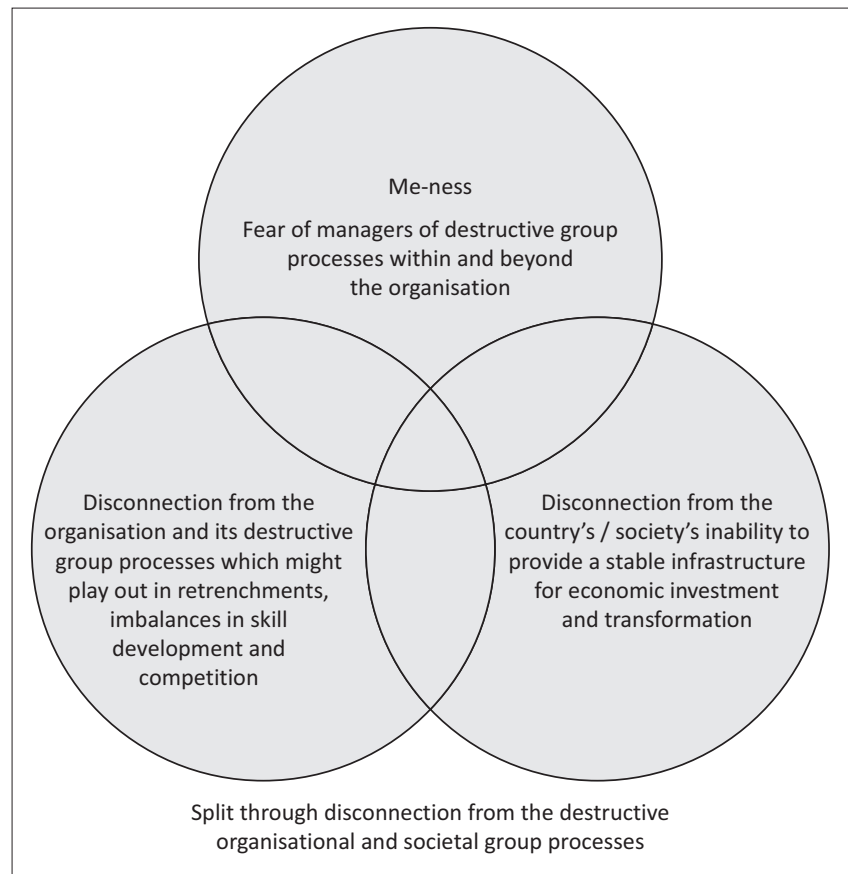

FIGURE 6: Me-ness.

and skills development. Some managers, therefore, disconnected from the organisation and presented themselves as being part of the global 4IR community, and being knowledgeable about and aware of the changes, whilst presenting the employees as rather unaware and uninformed, thereby creating a split that makes it easier to disconnect from the destructive processes within the organisation and within the country or society (e.g. not even providing the organisation with a proper infrastructure, stable electricity or Internet connections, etc.). Therefore, disconnections happen at two levels and display me-ness, representing a split between the managers and the organisation and society, as well as a positive projection (excitement) onto the technologically advanced international, global community of 4IR pioneers.

Finally, the data showed a strong idealisation across all the different levels of analysis (Klein, 1946; Mollon, 1986) of the 4IR processes, which are reflected in the description of excitement, new technological advantages, empowerment and motivation, a positive mindset and happiness experienced in the context of the 4IR changes. In their descriptions, managers highlight the technological advantages and the functional capacities of the 4IR, as described in previous research (Ployé, 1984; Tenconi, 2020).

The findings showed high levels of fear within the organisation (Huffington et al., 2004) to control trepidation of the 4IR. It is primarily an anxiety that is classified as endurance (Farlex Medical Dictionary, 2015; Menzies, 1993; Schein, 2009) presenting itself as the feeling of threat and shock and within the assumption that life is endangered. The findings also showed that several of the managers referred to fear and the recurring idea of job losses and retrenchments with regard to the employees, which might create limitations to flexibility, as previously described by Krantz (2001), and which are related to the dynamics of splitting, projection, projective identification and idealisation (Blackman, 2004), as discussed here.

\section{Practical implications}

The experience of managers of 4IR carries inherent anxiety that can only be coped with by splitting and comparing it with another (Czander, 1993). Management as an object is split between a good parent taking care of 4IR technological matters, and a bad parent, not taking care of people matters such as emotional and belonging needs (Klein, 1988). The object management is under attack because of its attachment to and preference for non-human 4IR objects and detachment from its nurturing parent egostate (Erskine, 2010; Greyvenstein \& Cilliers, 2012).

The idealisation of the past and blaming the present 4IR reality illustrated the fundamental split between past, present and future management (Cytrynbaum \& Noumair, 2004). Goodness and longevity were projected onto past management practices. Badness was projected onto present managers characterised by poor relationships (Gaitanidis, 2007; Greyvenstein \& Cilliers, 2012). Goodness was also projected onto future managers characterised by respect, dignity and the acknowledgement of needs.

Coping with anxiety around management is based on trusting the universal, systemic and unconscious life forces towards equilibrium, linked with an inner strength to survive the impact of the 4IR (Greyvenstein \& Cilliers, 2012). The underlying belief is that the moment there is too much of one side (such as uncertainty), its opposite will emerge in unexpected, surprising and interesting ways. For the present, the trust in life's fairness and balance is restored (Vansina \& Vansina-Cobbaert, 2008).

\section{Limitations and recommendations}

Future research needs to focus in more depth on feelings and their unconscious impact on the 4IR transformational processes. Thereby, culture- and context-specific research are needed to explore the differences and similarities of 4IR processes and their unconscious transformation underneath the surface of the organisation. On a practical note, organisations and managers need to be made aware of the new trends in the 4IR and the underlying unconscious processes within the organisation. On the one hand, managers within the organisation could undergo training to improve their understanding of intra- and interpsychological and organisational processes and the impact on organisational change and transformation within the 4IR contexts. On the other hand, consultants, researchers and others who work with 4IR conscious and unconscious crescendos, organisational composition and strategy, and the collaboration between the two need to become aware of the systems-psychodynamic processes occurring underneath the surface of an organisation to adjust their interventions to not only address dynamics above the 
surface but also to address dynamics below the surface. Thereby, they need to pay special attention to the feelings of all processes and the containment of anxiety, as well as the potential energy of excitement.

This study comes with certain limitations. It presents findings from one selected German multinational organisation. It is biased in terms of hierarchical levels within the organisation, having managers from only middle and top management responding to the interview questions. Furthermore, the data might be culturally biased and gender-biased because 15 male managers and 1 female manager participated in the study, representing the gender inequalities in the organisation as being a rather male-dominated, white field of work, particularly in management. In addition, the data were collected during an economically unstable and challenging time in post-apartheid South Africa, with growing crime rates and decreasing foreign investments. These external circumstances might have influenced the findings and the high anxiety and fear levels unconsciously within the organisation.

\section{Conclusion}

Systems psychodynamics research comprehends and fosters knowledge concerning the conscious and unconscious psychodynamics of working in an organisation. In this article, we focused on the feelings that managers experienced during the transformation towards 4IR in a selected organisation and their meaning-making within the SP framework. Findings indicated that more negative than positive feelings are experienced. Feelings that are predominantly experienced in the organisation are anxiety and excitement. Systems psychodynamic defences include splitting, projection, projective identification and idealisation. Thereby, managers create a split with regard to the employees' anxiety and excitement towards the 4IR processes.

\section{Acknowledgements}

The authors sincerely thank the German engineering organisation operating in South Africa and particularly the Chief Executive Officer (CEO) and the participating employees.

\section{Competing interests}

The authors have declared that no competing interest exist.

\section{Authors' contributions}

C.-H.M. was the project leader. Both R.M.O. and C.-H.M. wrote the manuscript.

\section{Funding information}

This research received no specific grant from any funding agency in the public, commercial or not-for-profit sectors.

\section{Data availability statement}

Data sharing is applicable to this article as new data were created and analysed in this study.

\section{Disclaimer}

The views and opinions expressed in this article are those of the authors and do not necessarily reflect the official policy or position of any affiliated agency of the authors.

\section{References}

Amado, G. (1995). Why psychoanalytical knowledge helps us understand organisations: A discussion with Elliot Jacques. Human Relations, 48(4), 351-358. https://doi.org/10.1177/001872679504800402

Apter, M.J. (1992). The dangerous edge: The psychology of excitement. New York, NY: Free Press.

Armstrong, D. (2005). Organization in the mind: Psychoanalysis, group relations and organizational consultancy. London: Karnac.

Barclay, L.J., \& Kiefer, T. (2019). In the aftermath of unfair events: Understanding the differential effects of anxiety and anger. Journal of Management, 45(5), 1802-1829. https://doi.org/10.1177/0149206317739107

Becker, T., \& Stern, H. (2016). Future trends in human work area design for cyberphysical production systems. Procedia CIRP, 57(2016), 404-409. https://doi. org/10.1016/j.procir.2016.11.070

Bion, W.R. (1961). Experiences in groups. London: Tavistock Publications.

Bion, W.R. (2003). Learning from experience. London: Karnac.

Blackman, J.S. (2004). 101 defences: How the mind shields itself. New York, NY: Brunner-Routledge.

Bolier, L., Haverman, M., Westerhof, G.J., Riper, H., Smit, F., \& Bohlmeijer, E. (2013). Positive psychology interventions: A meta-analysis of randomized controlled studies. BMC Public Health, 13, a119. https://doi.org/10.1186/1471-2458-13-119

Brunning, H. (2006). Executive coaching: Systems-psychodynamic perspective. London: Karnac.

Campbell, D. (2007). The socially constructed organisation. London: Karnac.

Campbell, D., \& Huffington, C. (2008). Organisations connected: A handbook of systemic consultation. London: Karnac.

Cannon, W.B. (1952). Bodily changes in pain, hunger, fear and rage. Boston, MA: Branford.

Cilliers, F., \& May, M. (2010). The popularisation of Positive Psychology as a defence against behavioural complexity in research and organisations. SA Journal of Industrial Psychology, 36(2), 1-10.

Cilliers, F., \& Terblanche, L. (2010). The systems psychodynamic leadership coaching experiences of nursing managers. Health SA Gesondheid 15(1), Art \#457, 1-9. experiences of nursing managers. Health
https://doi.org 10.4102/hsag.v15i1.457

Clarke, S., \& Hogget, P. (2009). Researching below the surface: Psycho-social research methods in practice. London: Karnac.

Colman, A.D., \& Bexton, W.H. (Eds.). (1975). Group relations reader 1. Washington, DC: A.K. Rice Institute.

Colman, A.D., \& Geller, M.H. (1985). Group relations reader 2. Jupiter, FL: The A.K. Rice Institute.

Creswell, J.W. (2013). Qualitative inquiry \& research: Choosing among five approaches (3rd ed.). London: Sage Publications.

Creswell, J.W., \& Plano Clark, V.I. (2011). Designing and conducting mixed methods research (2nd ed.). London: Sage Publications.

Cytrynbaum, S., \& Noumair, A. (2004). Group dynamics, organisational irrationality, and social complexity: Group relations reader 3. Jupiter, FL: A.K. Rice.

Czander, W.M. (1993). The psychodynamics of work and organizations. New York, NY Guilford.

Diamond, M.A. (2020). Psychoanalytic organisation theory and identity: A psychosocial framework. Journal of Psychosocial Studies, 13(1), 99-116. https://doi.org/10.133 2/147867320X15803493574409

Erskine, R. (2010). Life scripts: A transactional analysis of unconscious behaviour. London: Karnac.

Fitzpatrick, M.R., \& Stalikas, A. (2008a). Positive emotions as generators of therapeutic change. Journal of Psychotherapy Integration, 18, 137-154. https:// doi.org/10.1037/1053-0479.18.2.137

Fitzpatrick, M.R., \& Stalikas, A. (2008b). Integrating positive emotions into theory, research, and practice: A new challenge for psychotherapy. Journal of Psychotherapy Integration, 18, 248-258. https://doi.org/10.1037/10530479.18.2.248

Folkman, S. \& Moskowitz, J.T. (2000). Stress, positive emotion, and coping. Current Directions in Psychological Science, 9, 115-118. https://doi.org/10.1111/14678721.00073

Fraher, A.L. (2004). A history of group study and psychodynamic organizations. London: Free Association Books. 
Freud, S. (1921). Group psychology and the analysis of the ego: Complete works of Sigmund Freud. London: Hogarth.

Gaitanidis, A. (2007). Narcissism. A critical reader. London: Karnac.

Gould, L.J., Stapley, L.F., \& Stein, M. (2006). The systems psychodynamics of organizations: Integrating the group relations approach, psychoanalytic, and open systems perspectives. London: Karnac.

Greyvenstein, H., \& Cilliers, F. (2012). Followership's experiences of organisational leadership: A systems psychodynamic perspective. SA Journal of Industrial

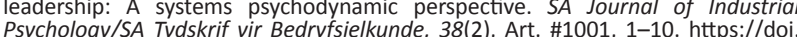
Psychology/SA Tydskrif vir Bedry
org/10.4102/sajip.v38i2.1001

Hassan, I., \& Ghauri, P.N. (2014). Evaluating companies for mergers and acquisitions. Book series. International Business and Management, 40, 75-89. https://doi. org/10.1108/S1876-066X20140000030009

Hoffmann, S., De Carvalho, A.F.P., Abele, D., Schweitzer, M., Tolmie, P., \& Wulf, V. (2019). Cyber-physical systems for knowledge and expertise sharing in manufacturing contexts: Towards a model enabling design. Computer Supported Cooperative Work (CSCW), 28, 469-509. https://doi.org/10.1007/s10606-019-09355-y

Huffington, C., Armstrong, A., Halton, W., Hoyle, L., \& Pooley, J. (2004). Working below the surface: The emotional life of contemporary organisations. London: Karnac.

James, C. (2010). The psychodynamics of educational change. In A. Hargreaves, A. Lieberman, M. Fullan, \& D. Hopkins (Eds.), Second international handbook of educational change (pp. 47-64). Dordrecht: Springer.

Johnson, J.L., Adkins, D., \& Chauvin, S. (2019). Quality indicators of rigor in qualitative research. American Journal of Pharmaceutical Education, 84(2), 1-22. https://doi. org/10.5688/ajpe7120

Kadir, B.A., \& Broberg, O. (2020). Human well-being and system performance in the transition to industry 4.0. International Journal of Industrial Ergonomics, 76, a102936. https://doi.org/10.1016/j.ergon.2020.102936

Kernberg, O.F. (1987). Projection and projective identification: Developmental and clinical aspects. Journal of the American Psychoanalytic Association, 35(4), 795-819. https://doi.org/10.1177/000306517602400403

Kets de Vries, M.F.R. (2007). Coach and couch. London: Palgrave.

Kiefer, T. (2005). Feeling bad: Antecedents and consequences of negative emotions in ongoing change. The International Journal of Industrial, Occupational and Organizational Psychology and Behavior, 26(8), 875-897. https://doi.org/10.1002/ job.339

Klein, L. (2005). Working across the gap: The practice of social science in organisations London: Karnac.

Klein, M. (1946). Notes on some schizoid mechanisms. In M.M.R. Khan (Ed.), Envy and gratitude (1975), pp. 1-24. London: Hogarth.

Klein, M. (1952). The mutual influence in the development of ego and id. Psychoanalatic Study Child, 7(1), 51-68. https://doi.org/10.1080/00797308.1952.11823152

Klein, M. (1975). Love, guilt, and reparation and other works, 1921-1945. London: Hogarth Press.

Klein, M. (1988). Envy and gratitude and other works 1946-1963. London: Hogarth.

Kok, B.E., Coffey, K.A., Cohn, M.A., Catalino, L.I., Vacharkulksemsuk, T., Algoe, S.B., ... Fredrickson, B.L. (2013). How positive emotions build physical health: Perceived positive social connections account for the upward spiral between positive emotions and vagal tone. Psychological Science, 24(7), 1123-1132. https://doi. org/10.1177/0956797612470827

Krantz, J. (2001). Dilemmas of organizational change: A systems psychodynamic perspective. In L.J. Gould, L.F. Stapley, \& M. Stein (Eds.), The systems psychodynamics of organizations: Integrating the group relations approach, psychoanalytic, and of organizations: Integrating the group relations approach,
open systems perspectives (pp. 133-156). London: Karnac.

Lawrence, W.G. (1999). Exploring individual and organisational boundaries: A Tavistock open systems approach. London: Karnac.

Lincoln, Y.S., \& Guba, E.G. (1985). Naturalistic inquiry. Beverly Hills, CA: Sage.

Lyubomirsky, S., King, L., \& Diener, E. (2005). The benefits of frequent positive affect: Does happiness lead to success? Psychological Bulletin, 131(6), 803-855. https:// doi.org/10.1037/0033-2909.131.6.803

Marris, P. (1974). Loss and change. London: Routledge Kegan Paul.

May, M.S. (2019). Lecturers through a stay-away action disowning shame: Interventions from a system psychodynamic perspective. In C.-H. Mayer \& E. Vanderheiden (Eds.), The bright side of shame (pp. 301-313). Springer Nature Switzerland AG: Cham. https://doi.org/10.1007/978-3-030-13409-9_20

Mayer, C.-H. (2020). Key concepts for managing organisations and employees turning towards the Fourth Industrial Revolution. International Review of Psychiatry, 32(5-6), 673-684. https://doi.org/10.1080/09540261.2020.1803220
Mayer, C.-H., Oosthuizen, R., Tonelli, L., \& Surtee, S. (2018). Women leaders as containers: Systems psychodynamic insights into their unconscious roles. Multidisciplinary Journal of Gender Studies, 7(2), 1606-1633. https://doi. org/10.17583/generos.2018.3217

Menzies, I.E.P. (1993). The functioning of social systems as a defence against anxiety London: Tavistock.

Mollon, P. (1986). A note on Kohut and Klein idealisation, splitting and projective identification. British Journal of Psychotherapy, 3(2), 162-164. https://doi. org/10.1111/j.1752-0118.1986.tb00967.x

Newton, J., Long, S., \& Sievers, B. (2006). Coaching in depth: The organisational role analysis approach. London: Karnac.

Ployé, P.M. (1984). A note on two important aspects of Kleinian theory 'projective identification' and 'idealisation'. The British Journal of Psychiatry, 145(1), 55-58. https://doi.org/10.1192/bjp.145.1.55

Poole, A.E., \& Malouff, J.M. (2019). Preliminary experimental evaluation of behavioral-cognitive method of increasing life excitement. Journal of Positive Psychology and Wellbeing, 3(1), 26-44.

Savvopoulos, S., Manolopoulos, S., \& Beratis, S. (2011). Repression and splitting in the psychoanalytic process. The International Journal of Psychoanalysis, 92(1), 75-96. https://doi.org/10.1111/j.1745-8315.2010.00363.x

Schein, E.H. (2009). The corporate culture survival guide. San Francisco, CA: Wiley.

Schneider, P. (2018). Managerial challenges of industry 4.0: An empirically backed research agenda for a nascent field. Review of Managerial Science, 12, 803-848. https://doi.org/10.1007/s11846-018-0283-2

Shaheen, M., \& Pradhan, S. (2019). Sampling in qualitative research. In M. Gupta, M. Shaheen, \& P. Reddy K (Eds.) Qualitative techniques for workplace dato analysis (pp. 25-51). IGI Global, Hershey: PA.

Sievers, B. (2009). Psychoanalytic studies of organizations: Contributions from the International Society for the Psychoanalytic Study of Organizations. London: Karnac.

Sin, N.L., \& Lyubomirsky, S. (2009). Enhancing well-being and alleviating depressive symptoms with positive psychology interventions: A practice friendly metaanalysis. Journal of Clinical Psychology: In Session, 65(5), 467-487. https://doi. org/10.1002/jclp.20593

Steyn, M., \& Cilliers, F. (2016). The systems psychodynamic experiences of organisational transformation amongst support staff. SA Journal of Industrial Psychology/SA Tydskrif vir Bedryfsielkunde, 42(1), a1367. http://doi.org/10.4102/ sajip.v42i1.1367

Tenconi, P.M. (2020). A projective transference in action: Reflections on the clinical use of an enactment. Transactional Analysis Journal, 50(2), 1-14. https://doi.org/ 10.1080/03621537.2020.1726656

The free dictionary by Farlex (2015). Farlex Medical Dictionary. Retrieved from http:// medicaldictionary.thefreedictionary.com/anxiety

Turquet, P.M. (1974). Leadership - The individual in the group. In G.S. Gibbard, J.J. Hartman, \& R.D. Mann (Eds.), Analysis of groups (pp. 349-386). San Francisco, CA: Jossey-Bass.

Van der Toorn, J., Tyler, T.R., \& Jost, J.T. (2011). More than fair: Outcome dependence, system justification, and the perceived legitimacy of authority figures. Journal of Experimental Social Psychology, 47(1), 127-138. http://doi.org/10.1016/j. jesp.2010.09.003

Vansina, L.S., \& Vansina-Cobbaert, M. (2008). Psychodynamics for consultants and managers. London: Wiley-Blackwell

Watson, D., Clark, L.A., \& Tellegen, A. (1988). Development and validation of brief measures of positive and negative affect: The PANAS scales. Journal of Personality and Social Psychology, 54(6), 1063-1070. https://doi.org/10.1037/00223514.54.6.1063f

Yin, R.K. (2009). Case study research design and methods (4th ed.). Thousand Oaks, CA: Sage.

Yin, R.K. (2014). Case study research: Design and methods (applied social research methods). Thousand Oaks, CA: Sage.

Zach, L. (2006). Using a multiple-case studies design to investigate the information seeking behavior of arts administrators. Library Trends, 55(1), 4-21. https://doi. org/10.1353/lib.2006.0055

Zuckerman, M. (1979). Sensation seeking. New York, NY: Wiley. 